\title{
The social media as an information distribution channel for libraries
}

\author{
E. V. Shevchenko
}

Odessa National Polytechnic University, Professor of the Information Activity and Media Communications Department, Odessa, Ukraine Corresponding author. E-mail: kafdid@i.ua

Paper received 13.11.17; Revised 16.11.17; Accepted for publication 18.11.17.

https://doi.org/10.31174/SEND-HS2017-146V24-14

\begin{abstract}
This research reveals the necessity of social media usage in the information service of libraries, identifies such social networks as Facebook and Google+ to implement them into the library activity, and discloses the concept of library profiles creating in social networks.
\end{abstract}

Keywords: social networks, informational service, exhibition activity, electronic technologies.

Relevance of research. The problem of library and information service, as well as interaction with library users, becomes more significant these days, and is of high relevance for research. Under the influence of sociocultural and technological transformations, which take place in the modern world, the stereotypes of relations between the library and society are changing. In the new environment, the library acts as an object of informational support, intensively implementing electronic technologies. Today, libraries are actively using the capabilities of virtual communities, social networks and blogging for their promotion.

Analysis. The research is based on the scientific works of N. M. Kushnarenko, A. A. Solyanik, N. V. Zbarovska, N. A. Bachynska and others. T. Novalska's discloses in her research the historical stages of reading development in libraries, as a branch of special library science. T. Koval investigates the evolution and structural changes of modern library readership. O. Bashun shows the importance of users' information needs analysis in order to justify the goals, tasks and directions of library transformations. A significant number of LIS publications is devoted to the methodology and results of modern users' information needs studying, etc.

The purpose of this paper is to identify the role of social media as a part of information service in libraries.

Findings. The traditional interpretation of social media definition, as an online service that unites people around common interests and provides them with convenient tools for communication and self-expression", is gradually displaced by others - means of information delivery (verbal, audio, visual) which work on the principle of a broadcast channel that covers a large audience, and function on an ongoing basis [1].

The modern social network can be a platform for discussion and promotion of library services. Developing web 2.0 services, libraries can gain new status, image, and capabilities. With the help of blogs and social networks, library services, materials and activities can be promoted more effectively through the Internet. In order to draw an interest to the library web-resources, it is necessary to make its content interesting, demonstrate various aspects of library life, and use a creative and informal style. An existing website does not make the blog / page in the social network unnecessary; on the contrary, these communicational channels have a number of advantages:

- Website is an official "mirror" of the library; the blog is an informal platform for talking with readers;

- The website guestbook is generalized and less flexible, unlike the forum in the social network, where each message finds its own topical section and can be discussed with readers; blog allows to pay new readers' attention to library reality;

- Considering the particular stylistics and location of the blog, the library psychologically becomes closer to the readers;

- A blog and a website are different means of informing about library activities, they allow maximizing the effectiveness of the information dissemination on the Internet. Social networks are a good instrument to view files, videos and photos of other users, leave comments, share opinions, and more. [2].

- An important thing is a possibility of operative information layout and getting feedback from online-users. Attracting an audience to the site is a separate and complex task that requires a special budget, for that reason, corporate blogs and social networking sites are created. There is a point of view that communicative bonding in social networks is faster than in real life, so it is logical that libraries should try to use social networks not as a means of influence, but as a tool of interaction.

There are several types of social networks, as follows: general-purpose networks, created for communicative purposes; professional social networks for communication among representatives of certain professions, they allow to find a job, colleagues, place a corporate news or press release, etc.; social networks of interest, where users can chat with like-minded people. To select a social network for libraries, it is important to pay attention to the widespread social media in Ukraine. The constantly updated information about them is posted on the website of the Bitly Science Lab [3]. Consequently, in Ukraine there are such widespread social networks: "Facebook", "Google+", "YouTube", "Instagram", "Linkedin" and "Twitter" (fig. 1).

Such online-services were excluded from the list: "Twitter" - due to a small number of local users, a limited number of signs in publication, difficulties with the feedback; "Linkedin" - a small number of local users and thematic scope. This network is not suitable for the permanent publication of library news, only to find new employees; "YouTube" due to a technical difficulty in using this network. In order to attract the attention of a sufficient number of users, video materials must be properly edited, of high-quality image and sound, requiring special technical equipment; "Instagram", since the publications on this network look like small photographs with a limited number of characters in signatures.

Such social networks left from the list: Facebook and Google+ (http://plus.google.com/). Functionally, Google+ 
is the social network created by Google, which appeared on June 28, 2011. Google+ developers believe that the social network allows to set the privacy setting for each user, and share content in a convenient and effective way $[4,5]$. The current implementation of social interaction is based on the principle of group formation through the specification of relationships - friends, classmates and groupmates, colleagues, family - the so-called circles of contacts (circles). Google developers point out that it is the "circles" that allow to control the level of access to social network users as it is in real life. This makes possible to sort the entire contact list by communication and interests. Google+ also can be set up so that information is received exactly as much as needed.

\section{Ukraine}

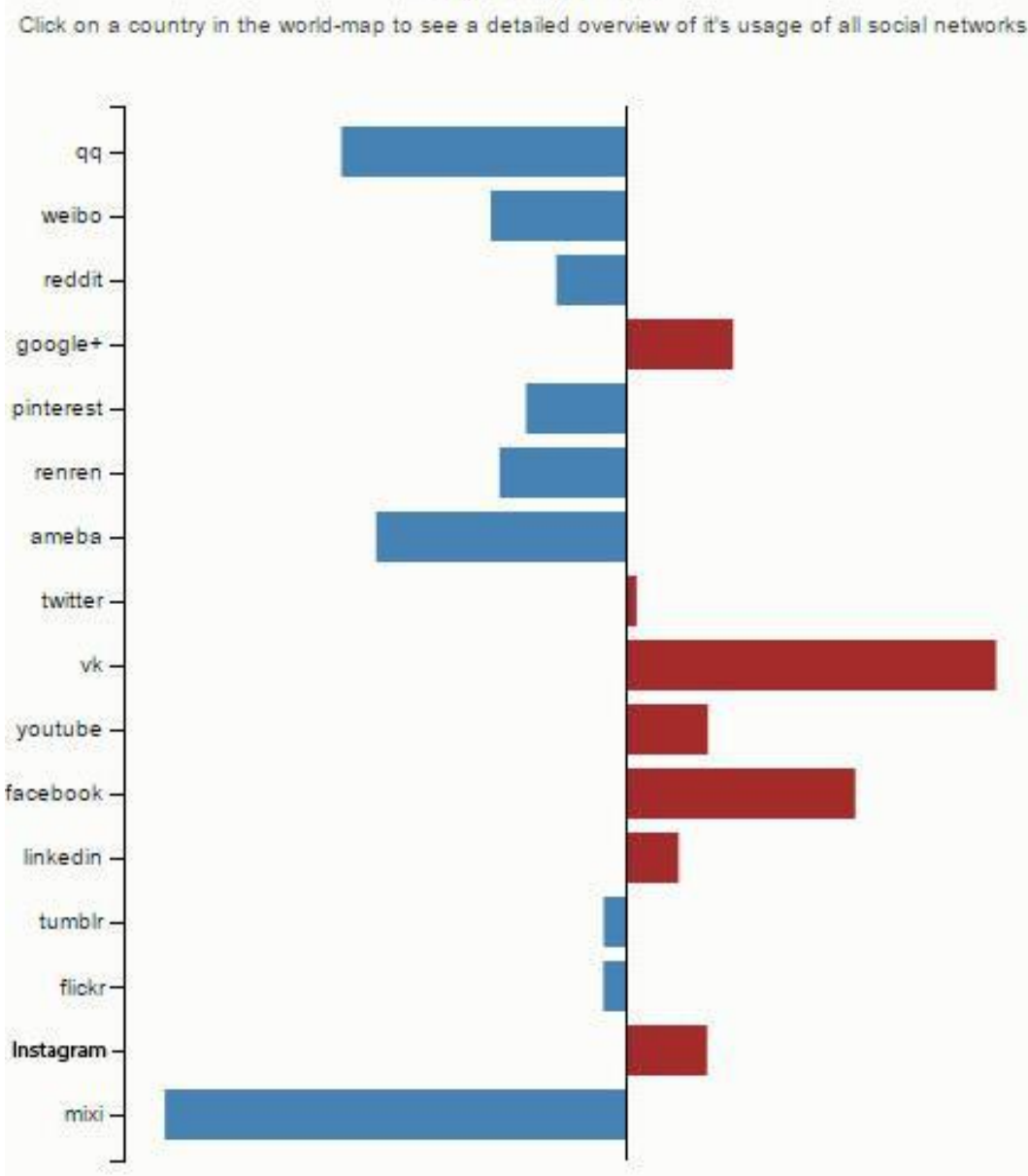

Fig. 1. Widespread social networks in Ukraine

Another potentially powerful tool is video conferencing. Through it, Google+ can attract attention of corporate segment users. This service is free and has a minimum number of settings, supporting simultaneous video communication for up to 10 people. Significant advantage of the social network is the possibility of "socializing the search". Not the search engine will now select the user's content, but the information will come to him through the recommendations of his friends.

The "Google+" platform is a powerful resource for libraries, as evidenced by the following facts:

- "Google+" is recognized as the fastest-growing social network, despite limited access to invitations.

- "Google+" is designed as a content sharing platform, which borrows many functions from other networks but makes them qualitative.

- "Google+" has solved the issue of privacy and "excessive exchange" that are present in "Facebook", at the same time provided a wide range of multimedia capabilities for its users.

- "Google+", with its own platform for sharing information, provides direct access to users' thoughts when it comes to quality content. Thus, users have the anytime access to library publications. The main feature of Google+ is the ability to use circles, where each user has the right to create separate categories of information, and share them in private messages.

However, the main effort is recommended to focus on "Facebook". Functional capabilities of this resource meet the needs of users the most, even exceed them. The resource is the most adapted for libraries promotion. It is the most convenient to communicate, organize and maintain professional and personal contacts with "Facebook". Through the experience, it has been found that the library community mainly communicates in "Facebook". These are library pages, librarians' profiles, and thematic library groups. Among them, there are "Year of libraries", "non-conference of library bloggers", etc.

The "I like" button (the so-called "like") allows the user 
to respond to a message, a photo or an event, without making significant efforts, creating a feeling of constant motion, interactivity, and response. Facebook is well-suited for finding useful and interesting contacts, managing friends' news feed, etc.

When developing the concept of a page, many libraries tend to rely on their own idea of what might be interesting to the visitor. It is important not to invite visit the library, but let the user become a part of community, creating a sense of movement, updating and eventivity on the page. The news topic for publications can be absolutely different - a book-gift day, meeting with interesting people, training seminars, etc.

In order to determine the focus area of library official page in social network, it is necessary to set the goals and tasks to be performed, which are: to become a means of communication optimizing with library users and community; a means of intra-corporate ties development by involving the library staff in content-producing process for the blog, informing the team about events, plans, new services and other areas of library activities. The tasks should be: increasing the image of the library; popularization of library services with the aim of their optimization, experience exchange; operative feedback obtaining; increasing the number of library website visitors. The project is designed for both internal and external audiences. The internal audience includes library staff, external - library users, partners and colleagues from other libraries, as well as curious readers.

The approximate directions of publications may include: library news (comments to the official publication on the site) and of the entire library world (for example, translated articles from foreign media), presentations of electronic and printed works, historical references about the library and its projects, debating points, library experience, innovation activity, information about services, etc.

During the process of publication, such principles should be taken into account:

- Easy text perception; the maximum text size is 16384 characters. It is recommended to record no longer than 280 characters, if the record is longer, some of it is hidden under the "Show all" button;

- If the text contains factual data, it is better to check the reliability of the information;

- Materials published on the page should relate to the subject of the group and not contain any unnecessary information;

- Using the whole functionality - fill the site not only with text, but also with photographs, surveys, pictures, audio and video materials;

- Updating the news;

- In order to simplify the process of messages search on a specific subject, insert special labels ("hashtags") in the text starting with the \# followed by letters and numbers without spaces;

- In order to attract readers, it is necessary to provoke them on emotions that "enliven" the activity of the group, but for librarian it is necessary to maintain his or her own neutrality; add surveys to publications to hold polls, competitions, get information about public opinion or simply to bring back to life the community, etc.

Conclusions. The role of social networks will be dominant on the Internet as a phenomenon of the present. Networks will turn into full-fledged platforms for different spheres of life. The total and widespread socialization of the whole Internet is expected [6,7]. It is necessary to pay attention to the communication quality in social media. Nowadays social network pages are more popular than websites due to the fact that they allow to make direct contact with the readers. In addition, social media are much more convenient for using - users do not need to visit another resource to obtain the necessary information.

Significant results in the field of work in social networks, stable growth of activity and number of participants, improvement of published materials quality, creation of a single style of web management, the optimal combination of entertaining and serious information in publications, the contrast of which positively affects the activity and interest of readers - the results of informational and documentary support of libraries.

\section{REFERENCES}

1. Parafet Yu.H. Vplyv zasobiv masovoi informatsii na formuvannia imidzhu derzhavnoi ustanovy : zb. nauk. prats / Yu. H. Padafet. - Dnipropetrovsk : Vyd-vo DRIDU NADU, 2003. $-50 \mathrm{~s}$.

2. Rubanovych A. O. Vystavkova diialnist $v$ Ukraini: tendentsii rozvytku / A. O. Rubanovych. - Rezhym dostupu: file:///C:/Users/User/Downloads/3314-8856-1-SM.pdf (data zvernennia 23.05. 2017).

3. Trachuk L. Virtualna vystavka: nova posluha biblioteky / L. Trachuk // Visnyk Knyzhkovoi palaty. 2007. №11. S. 36-38.

4. Ufymtseva O. H. Tekhnolohyia sozdanyia vyrtualnikh vystavok s pomoshchiu systemy YRBYS: novye vozmozhnosty y perspektyvy / O . H. Ufymtseva // Nauch. y tekhn. b-ky. 2014. - № 6. - S. 30-33.
5. Chekotovska O. E. Osnovni pidkhody do rozuminnia katehorii «elektronnyi dokument» [Elektronnyi resurs] / O. E. Chekotovska // Chasopys Kyivskoho universytetu prava. 2012. - №2. - Rezhym dostupa : http://kul.kiev.ua/images/chasop/2012_2/134.pdf.. - Nazva z ekrana.

6. Yak pravylno obraty bloh-platformu? [Elektronnyi resurs]. Rezhym dostupu: http://cityplan.in.ua/page/view/40 . - Nazva z ekranu.

7. Pidhrushnyi H. Vystavkova diialnist ta yii znachennia yak instrumentu rehionalnoho rozvytku / H. Pidhrushnyi, V. Pekar, A. Denysenko // Ukrainskyi heohrafichnyi zhurnal. 2009. № 1. S. 41-49.

\section{Использование социальных сетей как канала распространения информации о библиотеках}

Е. В. Шевченко

Аннотация. В статье обосновывается необходимость использования социальных сетей в информационном обслуживании библиотек, выделены социальные сети «Facebook», «Google+» для внедрения в деятельность библиотек, раскрыта концепция создания страниц библиотек в социальных сетях.

Ключевые слова: сочиальные сети, информачионное обслужсивание, выставочная деятельность, электронные технологии. 